\title{
Back pain and core strength in elite cycling
}

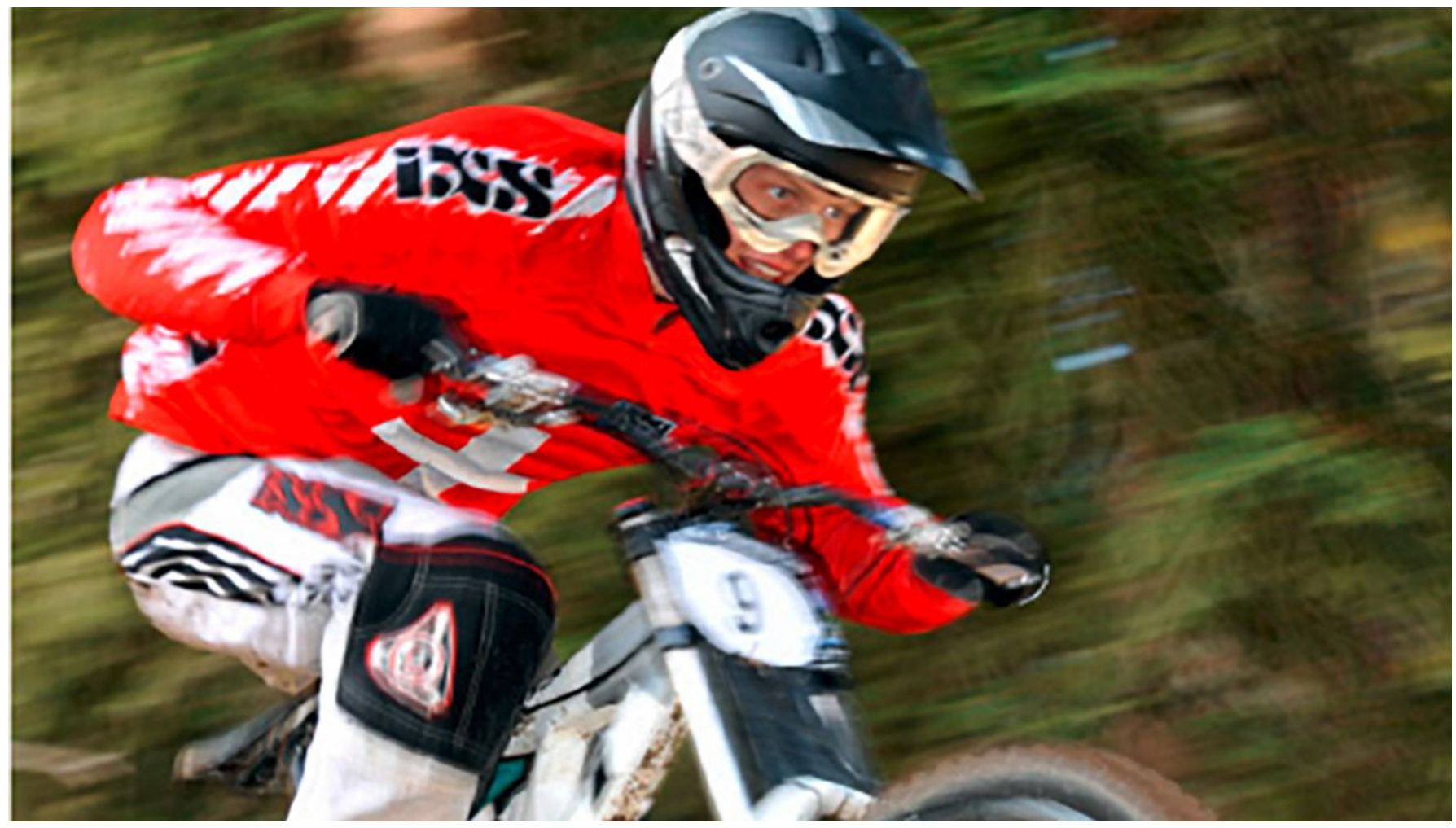

\section{Ruckstuhl L, Clénin G}

Sportmedizinisches Zentrum Bern-Ittigen, Haus des Sports, Switzerland

\section{Abstract}

Back pain is common among elite cyclists. Experiences of athletes and observations of coaches show that it may influence training quality and sometimes even limit performance during competition. Therefore the following study questions were investigated: 1) How many athletes of the Swiss cycling national teams suffer back pain during training or competition? 2) How good is athletes' core strength? 3) What correlation exists between back pain and core strength? 4) Does an intensified core strength training reduce back pain?

A total of 111 elite cyclists, 45 athletes ( $38 \mathrm{~m}$, 7f; $19.6 \pm 3.5 \mathrm{y}$ ) of technical disciplines (BMX, Trial, Downhill, $4 \mathrm{X}$ ) and 66 athletes (39 m, 27f; $19.5 \pm 5.8 \mathrm{y}$ ) of endurance disciplines (road, MTB, Cyclo-cross) all members of Swiss cycling national teams, took part in in the study. They performed a core strength test, got an instruction session on core strength training, and filled out a standardized questionnaire on back pain at time of testing and after four months of training. 
1) In Swiss elite cyclists back pain is frequent: In training every third suffers slight and every tenth rider moderate to heavy back pain. In competition roughly half of all riders are affected by back pain episodes, and $22.5 \%$ of all have moderate to heavy back pain impairing performance. 2) About one third of all elite cyclists has an insufficient core strength. 3) Having a good core strength of the dorsal muscle chain proved to be positively related to a lesser frequency of back pain. Whereas there was no such correlation between back pain and core strength of the ventral and lateral chain. 4) The 47.9\% of athletes intensifying their core strength training during the four months period could significantly reduce their back pain in cycling, in competition, and in daily life.

\section{Zusammenfassung}

Rückenschmerzen sind im Radsport relevant. Beobachtungen von Trainern und Athleten weisen darauf hin, dass die Beschwerden die Trainingsplanung stören und gelegentlich sogar die Wettkampfleistung beeinflussen können. Aus diesen Gründen wurde innerhalb der Schweizer Radsport-Nationalkader untersucht: 1) Wie viele Athleten haben Rückenschmerzen in Training oder Wettkampf? 2) Wie gut ist ihre Rumpfkraft? 3) Korreliert tieferes Rumpfkraftniveau mit Rückenschmerzen? 4) Kann Rumpfkrafttraining das Auftreten von Rückenschmerzen vermindern?

Bei 111 Spitzenradsportlern, 45 (38 m, 7f; $19.6 \pm$ 3.5y) aus technischen (BMX, Trial, Downhill, 4X) und 66 (39 m, 27f; $19.5 \pm$ 5.8y) aus ausdauerorientierten Disziplinen (Strasse, MTB, Radquer) wurde das Rumpfkraftniveau gemessen, ein gezieltes, sportartspezfisches Rumpfkrafttraining instruiert und mittels Fragebogen Auftreten und Intensität von Rückenschmerzen zum gleichen Zeitpunkt und nach vier Monaten individuellem Rumpfkraftttraining erneut erhoben.

1) Rückenschmerzen sind auch im Schweizer Spitzenradsport häufig. Im Training hat jeder dritte leichte und jeder zehnte Fahrer mittlere bis schwere Beschwerden. Im Wettkampf sind ziemlich genau die Hälfte aller Fahrer von Rückenschmerzen betroffen, Bei insgesamt 22.5\% wird deswegen auch die Wettkampfleistung beeinflusst. 2) Ungefähr ein Drittel aller Athleten hat ein ungenügendes Rumpfkraftniveau. 3) Das Kraftniveau der dorsalen Muskelkette korreliert signifikant mit vermindertem Auftreten von Rückenschmerzen, Für die laterale und ventrale Muskelkette zeigte sich kein statistischer Zusammenhang. 4) Die 47.9\% der Athleten, welche ihr Rumpfkrafttraining intensivierten, konnten Rückenschmerzen beim Radfahren, in Wettkämpfen und im Alltag signifikant reduzieren.

\section{Introduction and Study questions}

Experiences of top cyclists and coaches show that cyclists suffer often from back pain and are limited during training or competition. Several studies confirm these observations [1-5].

Core muscles stabilize the trunk and protect spine and pelvis. Strong and preserving trunk muscles are able to stabilize our body in gait, running, cycling, and in movement in general. Core muscles can, at least partially, compensate an unergonomic position, reduce overload of passive structures and help absorbing impacts. Malpositioning in sports should be avoided [6]. Deficits and dysbalances of the core muscles are known to be a risk factor for back pain [7,8]. And it has been shown that weak core muscles may be related to back pain $[9,10]$.

Incidence of back pain among top level cyclists, factors influencing their appearance, and core strength and its possible benefits were to our knowledge not yet investigated in elite cycling. 
We therefore asked the following study questions:

1) How many athletes of the Swiss cycling national teams suffer from back pain during training or competition?

2) How good is athletes' core strength? Are there differences between cycling disciplines?

3) Which correlation exists between back pain and core strength?

4) Does an intensified core strength training reduce back pain?

\section{Methods}

\section{Subjects}

111 elite cyclists, all Swiss national team members took part in the study. 66 were endurance athletes practicing either road cycling, MTB, or cyclo-cross (39 m, 27f; $19.5 \pm 5.8$ year) and 45 technical athletes practicing either BMX, Trial, Downhill, or 4X (38 m, 7f; $19.6 \pm 3.5 y e a r)$.

Average BMI was at $21.2 \pm 2$. Training hours per week were in average at $11.5 \pm 5 \mathrm{~h}$.

\section{Study design}

To evaluate back pain a modified Oswestry-Disability-Index was used. The Oswestry-Disability-Index is one of the most frequently used questionnaires to evaluate disability during different activities due to back pain [11,12]. Out of ten questions in the original questionnaire six about disabilities in everyday life remained (pain intensity, lifting, sitting, standing, sleeping, traveling) and four questions were adapted to back pain in athletes' life: one on cycling in general, one on training, one on competitions, and one on frequency of back pain.

To evaluate core strength a testing consisting out of three exercises according to Swiss Olympic standards was done $[18,19]$. One exercise for the ventral, one for the lateral, and one for the dorsal muscle chain 


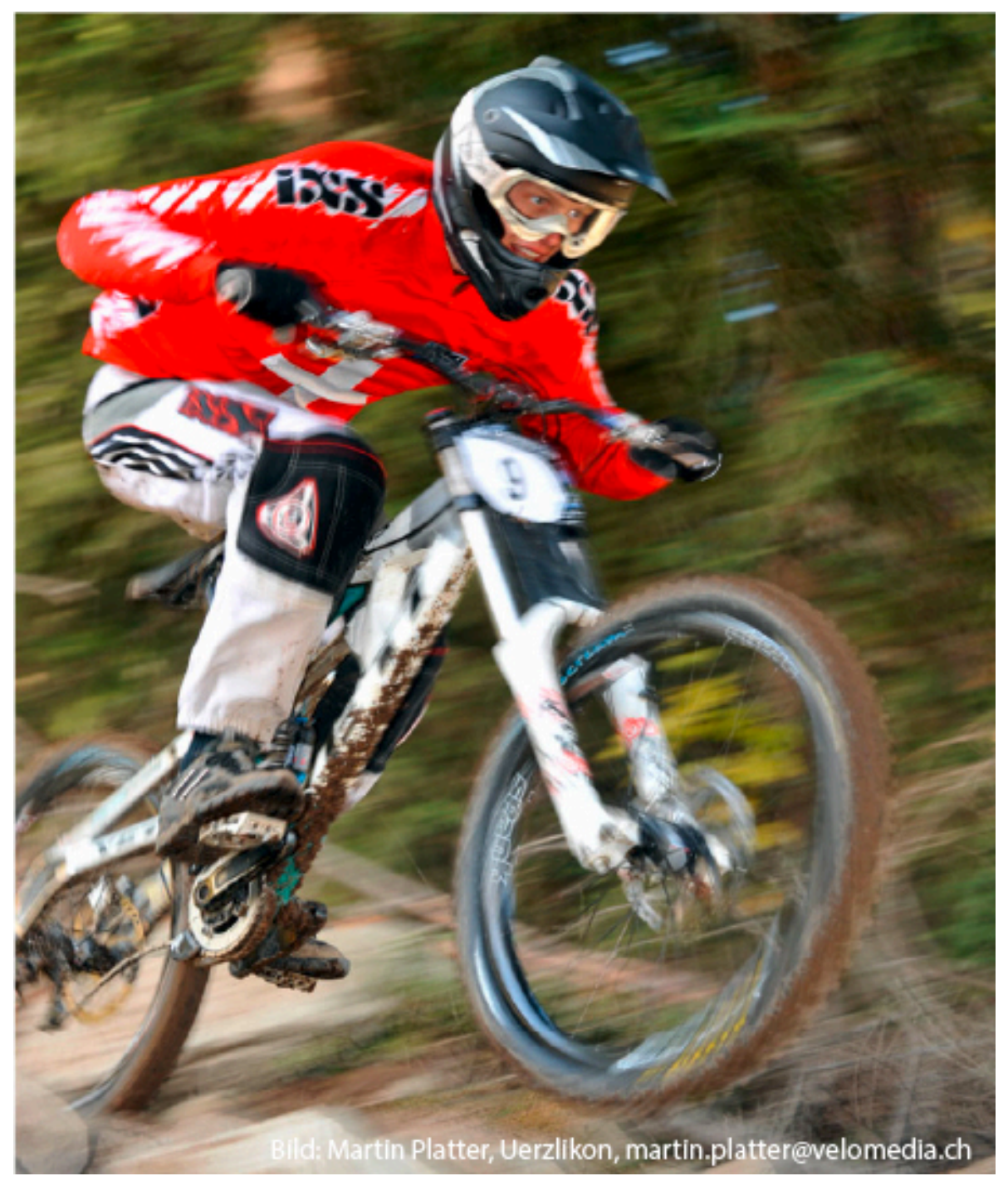

respectively. 


\begin{tabular}{|c|c|c|}
\hline time $1(\mathrm{~T} 1)$ & $\begin{array}{l}\text { Further training intervention } \\
\text { ( } 4 \text { months) }\end{array}$ & time $2\left(T_{2}\right)$ \\
\hline $\begin{array}{l}\text { - Core strength testing } \\
\text { - Back pain questionnaire } \\
\text { - Questionnaire on training in general and } \\
\text { core strength training before } \\
\text { - Sports medical exam } \\
\text { - Instruction of a core strength training } \\
\text { - Distribution of a brochure explaining } \\
\text { importance of core strength and show- } \\
\text { ing a series of practical exercises }\end{array}$ & $\begin{array}{l}\text { - Individual core strength training ac- } \\
\text { cording to the distributed brochure } \\
\text { - Evaluation of the sitting position on } \\
\text { the bicycle }\end{array}$ & $\begin{array}{l}\text { - Back pain questionnaire } \\
\text { - Questionnaire on training in gen- } \\
\text { eral and core strength training in } \\
\text { the last } \\
4 \text { months }\end{array}$ \\
\hline
\end{tabular}

Test 1: ventral core strength testing

From the basic supine position (elbow pushup, upper arm vertical, forearm parallel, legs extended standing on toetips. Shoulder joint, trochanter major and ankle in one line) the athletes lift up one foot after the other alternating.

Test 2: lateral core strength testing From basic sideward position (elbow pushup in preferred lateral position, shoulder girdle, bottom and heel touching the wall, upper arm vertical) the athlete moves the pelvis and whole body downwards touching the ground and lifting it up to neutral position in a rhythm of 2 seconds.

Test 3: dorsal core strength testing

From basic position (feet firmly hold in the wall bars, legs and whole body in horizontal position lying over a board, spina iliacae anterior superior four centimeters away from the edge, upper body freely hanging over) the athlete moves the trunk in a rhythm of 2 seconds down to $30^{\circ}$ flexion and back up to the horizontal line.

Athletes executed these three tests as long as possible. Time measured in seconds for the correct execution was equivalent to athlete's individual performance. Results were compared with reference values from a former study with more than two hundred elite athletes of different sports, indicating the following results as being sufficient: ventral core: 101 seconds, lateral core: $50 \mathrm{sec}$, dorsal core: $70 \mathrm{sec}$ [18].

The same group of authors evaluated this testing procedure further in another study concluding that core strength testing of the ventral, lateral and dorsal muscle chain is reliable and can be used to assess core strength of healthy elite athletes as a prerequisite for good sport performance and prevention of injuries [19].

Furthermore national team coaches appraised the sitting position on the bicycle for each of their athletes with a given scoring system: "strongly tilting forward" - "tilting forward" - "neutral” - "tilting backward" "strongly tilting backward" as shown on pictures.

\section{Results}

\section{Back pain}

Whereas $21.6 \%$ are free of pain, $31.5 \%$ suffer at least once a month back pain. $37.9 \%$ are having back pain 
episodes two to seven days a month and $9 \%$ suffer back pain more often. Six athletes indicated to suffer back pain nearly every day.

In training 34.2\% athletes suffer slight back pain, other $9.9 \%$ suffer moderate to very heavy back pain which impairs training quality. In competition $27.9 \%$ suffer slight back pain other $22.5 \%$ suffer moderate to very heavy back pain. During activities of daily life such as lifting, sitting, standing, sleeping and travelling $54.1 \%$ suffer slight back pain. Only $4.5 \%$ of athletes are moderately to heavily limited in daily life because of back pain. The study shows that more athletes in endurance disciplines (64.1\%) than athletes in technical disciplines suffer back pain $(\mathrm{p}<0.0005)$.

\begin{tabular}{|c|c|c|c|c|c|c|}
\hline \multirow[b]{2}{*}{$\begin{array}{l}\text { assessment of } \\
\text { core strength }\end{array}$} & \multicolumn{3}{|c|}{ technical athletes $(n=45)$} & \multicolumn{3}{|c|}{ endurance athletes ( $n=66$ ) } \\
\hline & $\begin{array}{l}\text { ventral core } \\
\text { strength }\end{array}$ & $\begin{array}{l}\text { lateral core } \\
\text { strength }\end{array}$ & $\begin{array}{l}\text { dorsal core } \\
\text { strength }\end{array}$ & $\begin{array}{l}\text { ventral core } \\
\text { strength }\end{array}$ & $\begin{array}{l}\text { lateral core } \\
\text { strength }\end{array}$ & $\begin{array}{l}\text { dorsal core } \\
\text { strength }\end{array}$ \\
\hline sufficient & $69.1 \%$ & $64.3 \%$ & $50 \%$ & $65.6 \%$ & $62.5 \%$ & $70.3 \%$ \\
\hline $\begin{array}{l}\text { slightly insuffi- } \\
\text { cient }\end{array}$ & $19 \%$ & $28.6 \%$ & $38.1 \%$ & $17.2 \%$ & $26.6 \%$ & $25 \%$ \\
\hline insufficient & $11.9 \%$ & $7.1 \%$ & $11.9 \%$ & $17.2 \%$ & $10.9 \%$ & $4.7 \%$ \\
\hline
\end{tabular}

\begin{tabular}{|l|l|l|l|l|l|l|l|l|}
\hline & \multicolumn{3}{|l|}{ ride a bicycle } & training & & \multicolumn{2}{l|}{ competition } & daily life \\
\hline & start & after 4 months & start & after 4 months & start & after 4 months & start & after 4 months \\
\hline no back pain & $26.7 \%$ & $51.1 \%$ & $62.2 \%$ & $73.3 \%$ & $44.4 \%$ & $62.2 \%$ & $42.2 \%$ & $53.3 \%$ \\
\hline slight back pain & $44.4 \%$ & $40.00 \%$ & $28.9 \%$ & $24.4 \%$ & $33.3 \%$ & $28.9 \%$ & $57.8 \%$ & $46.7 \%$ \\
\hline $\begin{array}{l}\text { moderate to very } \\
\text { heavy back pain }\end{array}$ & $28.9 \%$ & $8.9 \%$ & $8.9 \%$ & $2.2 \%$ & $22.2 \%$ & $8.9 \%$ & $0.00 \%$ & $0.00 \%$ \\
\hline
\end{tabular}

Table 2: Back pain before and after the intervention (athletes who intensified their core strength training $\mathrm{n}=45$ )

\section{Core strength}

The results of the core strength testing showed that only $67.6 \%$ had sufficient ventral core muscles, $62.2 \%$ lateral muscles, and $62.2 \%$ dorsal muscles. Technical and endurance athletes did not differ in their test results of the ventral and lateral core strength, but endurance athletes showed a significantly better dorsal core strength than their technical counterparts $(p=0.001)$. Looking at the duration of dorsal core exercise the median in endurance athletes was $107 \mathrm{sec}$ whereas the median in technical athletes was 91.5 sec only. (Table 1) 


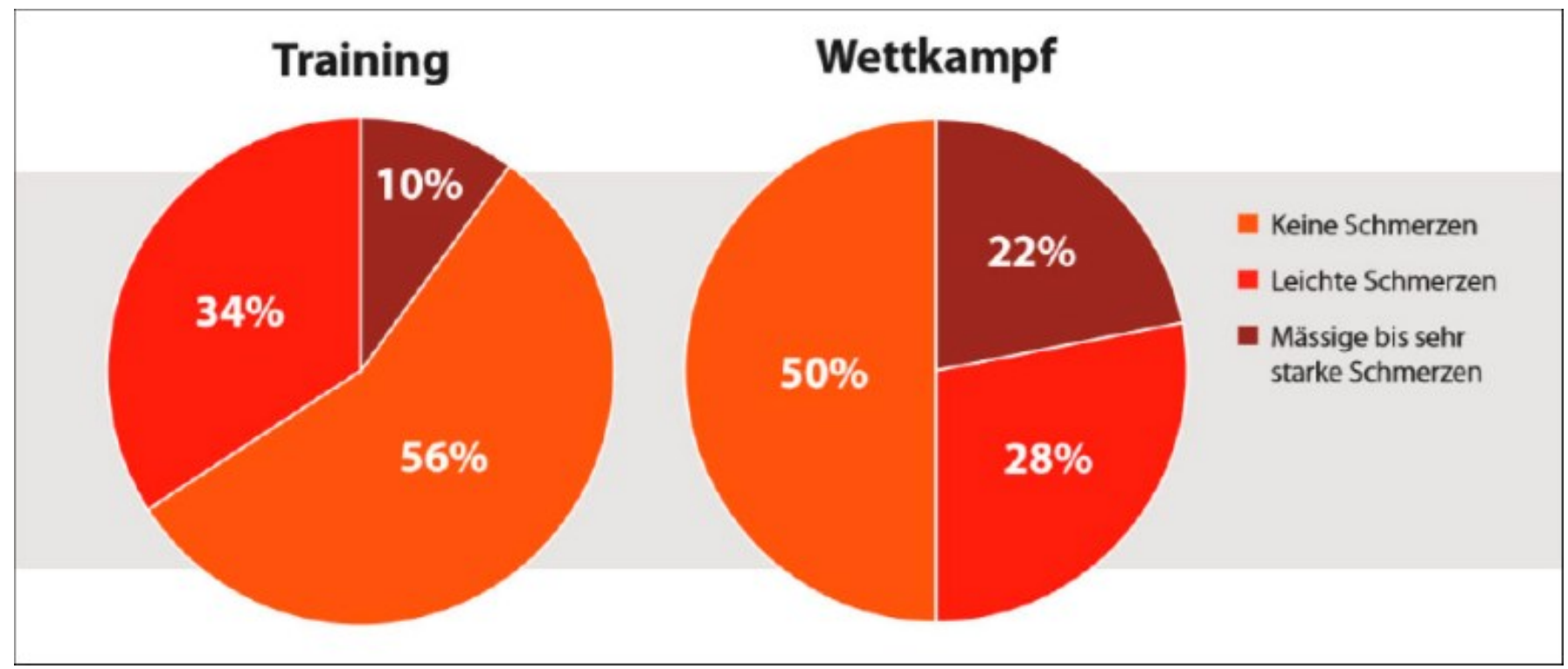

Grafik 1: Prozentuale Verteilung der Stärke der Rückenschmerzen während dem Training und Wettkampf

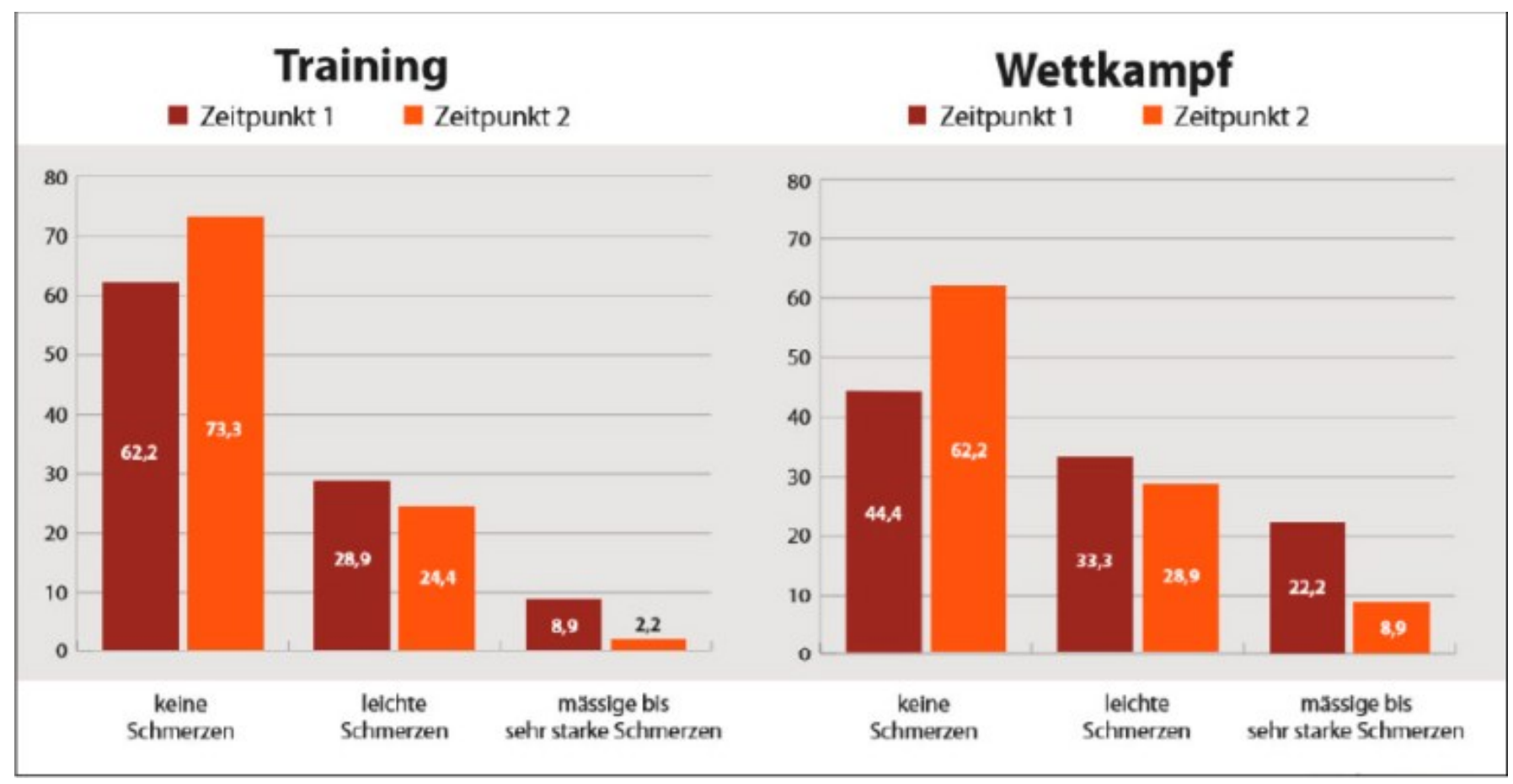

Grafik 2: Rückenschmerzen vor und nach der Interventionsphase

\section{Statistical analysis}

The bivariate correlation analysis showed no significant correlation between back pain and muscle strength neither for the ventral nor the lateral core muscles. However a significant correlation between back pain during training and strength of the dorsal core muscle chain $(r=0.231 ; p=0.017)$ could be demonstrated.

The study showed no significant correlation of back pain and sitting position on the bicycle. But there was a significant correlation between average training time and back pain. This means the 
longer training time the higher incidence of back pain $(r=0.277 ; \mathrm{p}=0.005)$.

The bivariate correlation analysis by Spearman as well as the multiple ordinal regression analysis showed a significant influence of training time and dorsal core strength on back pain during training $(\mathrm{p}=0.021 ; \mathrm{p}=$ $0.02)$.

$47.9 \%$ of athletes increased core strength training during the 4-month-intervention. They could significantly reduce back pain during cycling $(\mathrm{p}=0.003)$, back pain in competition $(\mathrm{p}=0.007)$ and during daily life $(p=0.028)$. Their level of back pain in training however did not change significantly. 


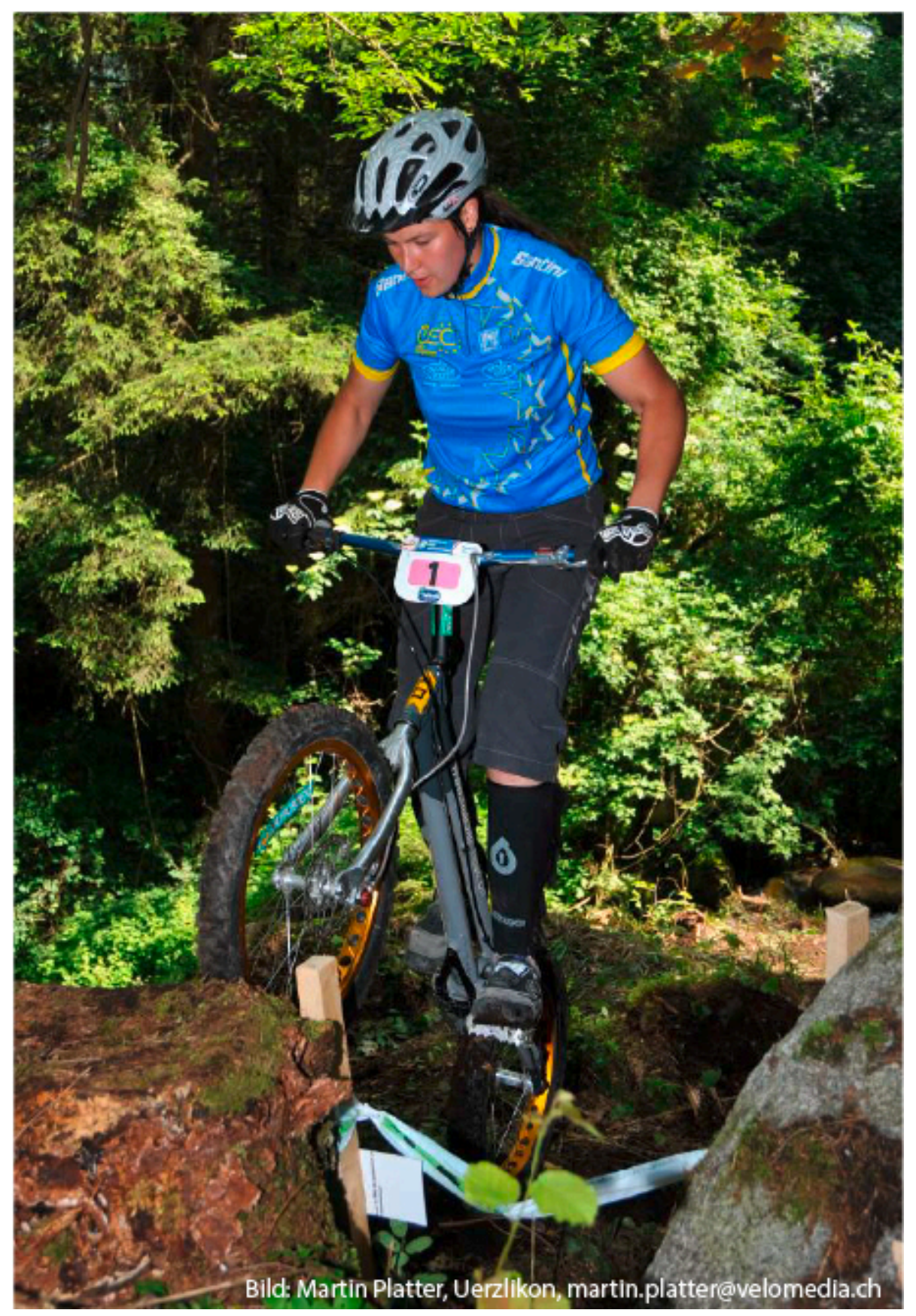

\section{Discussion}

Several studies report an incidence of back pain in cycling varying from 20 to $60 \%$ of all riders [1-3]. Our data confirm these findings: Among the tested 111 Swiss elite cyclists a total of $44.1 \%$ had back pain in training and 51.4\% in competition: Looking at athletes with back pain impairing training respectively performance during competition we look at a percentage of $9.9 \%$ in training and $22.5 \%$ in competition. Our data suggest that influence of core strength of the ventral and lateral chain on back pain is rather low. 
But a significant correlation between back pain during training and strength of the dorsal core muscles could be demonstrated. Our findings go along with the literature $[9,13]$.

The correlation between training time and back pain is not surprising as it probably just shows the higher demands of those athletes having longer training hours. This finding supports the argumentation that elite athletes have a higher need for an adequate core stability compared to the normal population.

As two studies with a non-sporty population showed less back pain after core strength training [14,15] the present data confirm these findings also for elite cyclists. Athletes who increased core strength training lowered significantly frequency of back pain, not only during cycling and in competitions but also in daily life.

\section{Acknowledgements}

The authors thank all athletes of Swiss national teams who took part in the study. Special thanks to all coaches and officials of the Swiss Cycling federation who initialized the study and supported their realization.

\section{Author}

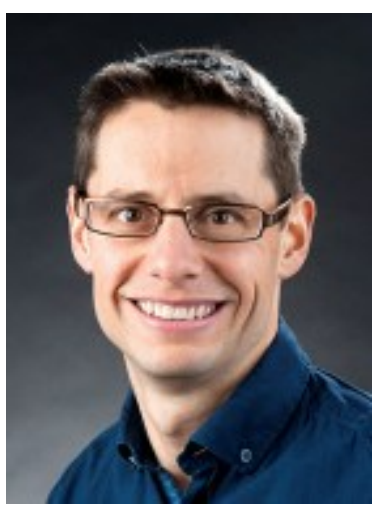

Ruckstuhl Lukas

Sportmedizinisches Zentrum

Bern-Ittigen, Haus des Sports,

Switzerland,

lukas.ruckstuhl@gmail.com

\section{Co-Author}


Clénin German

2005-2013 CMO Swiss Cycling,

CMO Swiss Ski Freestyle,

Verbandsarzt Swiss Orienteering und

Swiss Athletics,

Sportmedizinisches Zentrum

Bern-Ittigen, Switzerland

\section{Literature}

1. Callaghan M, Jarvis Ch. Evaluation of Elite British Cyclists: The role of the squad medical. Br J Sports Med. 1996;30:349-353.

2. Weiss B. Nontraumatic injuries in amateur long distance bicyclists. Am J Sports Med. 1985;13:187-192.

3. Wilber et al. An Epidemiological Analysis of Overuses Injuries among Recreational Cyclists. Int J Sports Med. 1994;16:201-206.

4. Burnett A et al. Spinal kinematics and trunk muscle activity in cyclists: a comparison between healthy controls and non-specific chronic low back pain subjects - a pilot investigation. Manual Therapie. 2004; 9:211-219.

5. Thompson M, Rivara F. Bicycle-Related Injuries. American Family Physician. 2001;63:2007-2014.

6. Cotta H, Sommer H. Ursachen und Behandlung des Rückenschmerzes bei Sportlern. Der Chirurg. 1988;59:708-712.

7. Dalichau S, Scheele K. Stellenwert des aqualen Funktionstrainings in der Therapie chronischer Rückenschmerzen. Physikalische Medizin, Rehabilitationsmedizin, Kurortmedizin. 2002;13:35-41.

8. Uhlig H. Die Rekonditionierbarkeit chronischer Rückenpatienten mit muskulärer Insuffizienz. Manuelle Medizin. 1999;37:40-45.

9. Dalichau S et al. Effekte muskelkräftigender Massnahmen zur Wirbelsäulenprotektion. Bewegungstherapie und Gesundheitssport. 2005; 21:6-12.

10. McNeill $\mathrm{T}$ et al. Trunk strengths in attempted flexion, extension, and lateral bending in healthy subjects and patients with low-back disorders. Spine. 1980;5:529-538.

11. Schifferdecker-Hoch F, Denner A. Mobilitäts-, Muskelkraft- und Muskelleistungsfähigkeitsparameter der Wirbelsäule. Alters- und geschlechtsspezifische Referenzdaten. Manuelle Medizin. 1999; 37:30-33.

12. Fairbank J, Pynsent P. The Oswestry Disability Index. Spine. 2000; 25:2940-2953.

13. Mannion et al. Development of a German version of the Oswestry Disability Index. Part 1: crosscultural adaption, reliability and validity. Spine. 2004;15:55-65. 
14. Roland M, Fairbank J. The Roand-Morris Disability Questionnaire and the Oswestry Disability Questionnaire. Spine. 2000;25:3115-3124.

15. Dalichau et al. Effekte muskelkräftigender Massnahmen zur Wirbelsäulenprotektion. Bewegungstherapie und Gesundheitssport. 2005; 21:6-12.

16. Biggoer R et al. Kräftigere Rückenmuskeln bedeuten weniger Schmerzen. Deutsche Zeitschrift für Sportmedizin. 1997;48:73.

17. Mannion et al. Lumbale Rückenschmerzen. Vergleich von drei aktiven Therapieverfahren. Manuelle Medizin. 2001;39:170-176.

18. Bourban P et al. Grundkraftanforderungen im Spitzensport: Ergebnisse eines 3-teiligen Rumpfkrafttests. Schweizerische Zeitschrift für Sportmedizin und Sporttraumatologie. 2001;49:73-78.

19. Tschopp $\mathrm{M}$ et al. Messgenauigkeit eines 4-teiligen, standardisierten dynamischen Rumpfkrafttests: Erfahrungen mit gesunden männlichen Spitzensportlern. Schweizerische Zeitschrift für Sportmedizin und Sporttraumatologie. 2001;49:67-72.

20. Asplund C, Webb C, Barkdull T. Neck and Back Pain in Bicycling. Current Sports Medicine Reports. 2005; 4:271-274.

21. Dingerkus M et al. Verletzungen und Überlastungsschäden beim Mountainbiken. Deutsche Zeitschrift für Sportmedizin. 1998;49:242-244.

22. Froböse I, Lücker B, Wittmann K. Überlastungssymptome von Mountainbikern - eine empirische Untersuchung mittels Fragebogenerhebung. Deutsche Zeitschrift für Sportmedizin. 2001;52:311-315.

23. Manninen J. Kallinen M. Low back pain and other overuse injuries in a group of Japanese triathletes. British Journal of Sports Medicine. 1995;30:134-139.

24. Mellion M. Common cycling Injuries. Management and Prevention. Sports Medicine. 1991;11:52-70.

25. Mellion M. Neck and back pain in bicycling. Clinics in Sports Medicine. 1994;13:137-160. 